\title{
ADSORPTION OF NICKEL(II) IONS FROM AQUEOUS SOLUTION USING BANANA PEEL AND COCONUT SHELL
}

\author{
Babatope Olufemi $^{1 *}$, Omolola Eniodunmo ${ }^{1}$ \\ ${ }^{1}$ Chemical and Petroleum Engineering Department, University of Lagos, Akoka, Yaba, Lagos, Nigeria
}

(Received: September 2016 / Revised: March 2017 / Accepted: March 2017)

\begin{abstract}
This work investigates the comparative adsorptive removal of $\mathrm{Ni}$ (II) ions from aqueous solution using coconut shell and banana peel. Optimum conditions for adsorption were determined by experimental design, while Analysis of Variance (ANOVA) and BonferroniHolm Posthoc significance statistical tests on operational parameters were also conducted. The parametric effect of adsorbate dose, adsorbent dose, $\mathrm{pH}$, contact time, particle size and temperature were varied individually, and their effect on the percentage of Ni (II) ion removal was estimated. The maximum percentage removal was achieved at a $\mathrm{pH}$ of 8.0 by both adsorbents. The optimum conditions obtained for both adsorbents were $4.5 \mathrm{~g}$ adsorbent dose, 30 min contact time and $25{ }^{\circ} \mathrm{C}$ for coconut shell, and $4.5 \mathrm{~g}$ adsorbent dose, 120 mins and $25{ }^{\circ} \mathrm{C}$ for banana peel. The Langmuir isotherm best described the adsorption, with correlation coefficient $\left(\mathrm{R}^{2}\right)$ values of 0.9821 and 0.9744 for banana peel and coconut shell respectively. The mean free energy from the Dubinin-Radushkevich isotherm suggested chemisorption, and the adsorption mechanism was found to fit the second order.
\end{abstract}

Keywords: Adsorption; ANOVA; Banana peel; Coconut shell; Nickel (II) ions

\section{INTRODUCTION}

Coconut shell and banana peel are low cost adsorbents usually regarded as agricultural waste. Various studies have analyzed their adsorbing characteristics using different adsorbates and conditions. In various capacities, adsorption depends on the characteristics of the individual adsorbent, the extent of surface modification, and the initial concentration of the adsorbate, temperature, $\mathrm{pH}$, adsorbent dosage and size, among other variables. Annadurai et al. (2002) worked on the adsorption of heavy metals from water using banana and orange peel. At $30{ }^{\circ} \mathrm{C}$, adsorption capacity decreased in the order $\mathrm{Pb}^{2+}>\mathrm{Ni}^{2+}>\mathrm{Zn}^{2+}>\mathrm{Cu}^{2+}>\mathrm{Co}^{2+}$ for both adsorbents, and rose with increasing $\mathrm{pH}$. Song et al. (2013) described the removal of $\mathrm{Pb}^{2+}$ ions from aqueous solution using coconut shell, activated with $\mathrm{KOH}$. The Freundlich isotherm described the adsorption data, while kinetics indicated a pseudo-second order kinetic model. In addition, Olayinka et al. (2009) investigated the removal of $\mathrm{Cr}$ (VI) and $\mathrm{Ni}$ (II) from industrial waste effluents using adsorption. The adsorption mechanism was found to fit the pseudo second order after evaluation with pseudo first order and second order kinetics. Abbasi et al. (2013) carried out a study on the adsorptive removal of $\mathrm{Co}^{2+}$ and $\mathrm{Ni}^{2+}$ by banana peel from aqueous solution. The maximum amounts of $\mathrm{Co}^{2+}$ and $\mathrm{Ni}^{2+}$ adsorbed $\left(\mathrm{q}_{\mathrm{m}}\right)$, from the Langmuir isotherm were 9.02 and $8.91 \mathrm{mg}$ per gram of banana peel, respectively.

Abbas et al., (2013) also studied the potentiality of banana peel to remove cyanide ion pollutant

*Corresponding author's email: bolufemi@yahoo.com, Tel: +2348023162183

Permalink/DOI: https://doi.org/10.14716/ijtech.v9i3.1936 
from waste water using an adsorption process by simulating a synthetic aquatic solution; maximum removal efficiency was $95.65 \%$ for cyanide ion removal. Okafor et al. (2012) explored the adsorption capacity of coconut shell for the removal of $\mathrm{Pb}^{2+}, \mathrm{Cu}^{2+}, \mathrm{Cd}^{2+}$ and $\mathrm{As}^{3+}$ from aqueous solutions. Adsorption capacity followed the trend $\mathrm{Pb}^{2+}>\mathrm{Cu}^{2+}>\mathrm{Cd}^{2+}>\mathrm{As}^{3+}$ and the kinetic treatment gave a pseudo second order type, while the Freundlich adsorption isotherm best described the adsorption. Soco and Kalembkiewicz (2013) worked on the adsorption of $\mathrm{Ni}^{2+}$ and $\mathrm{Cu}^{2+}$ ions from aqueous solution using coal fly ash. Optimum conditions of adsorption of $\mathrm{Cu}$ and $\mathrm{Ni}$ ions in the systems were established and the coefficient of adsorption was obtained using the Freundlich and Langmuir equations. Divakaran et al. (2012) also studied the adsorption of $\mathrm{Ni}$ (II) ions and $\mathrm{Cr}$ (VI) ions by chitin and chitosan when both ions were present together. The adsorption of $\mathrm{Cr}(\mathrm{VI})$ ions was much lower than that of $\mathrm{Ni}$ (II) ions.

Garba et al. (2016) reported on the ideal conditions for the adsorption of $\mathrm{Ni}$ (II) and Cd (II) ions onto Modified Plantain Peel (MPP) from aqueous solution. The Langmuir model and pseudo second order kinetics best described the two adsorption processes. The factors, effects and mechanisms of the adsorption of $\mathrm{Hg}$ (II), Cd (II) and $\mathrm{Ni}$ (II) on charged liposomes was reported by Gong et al. (2018). Attention was paid to the effect of $\mathrm{pH}$, ionic strength and particle size of the liposomes on sorption. The mutual effects between graphene oxide and Ni (II) ions with regard to their adsorption and co-adsorption on two minerals (goethite and hematite) in aqueous phase have been reported (Sheng et al., 2018). A pseudo second order kinetic model with chemisorption was reported by Rao and Khan (2017) in the adsorption of Ni (II) on alkalitreated pineapple residue in batch and column studies. The influence of metal ion concentration and $\mathrm{pH}$ was investigated by Pino et al. (2006) in the biosorption of cadmium by green coconut shell powder. In another useful account of agricultural waste, banana peel particles have been effectively used as a replacement for asbestos in brake pad manufacture (Idris et al., 2015).

This present work is focused on the separate removal of nickel (II) ions from an aqueous solution using coconut shell and banana peel, to study the comparative effect of various parameters such as $\mathrm{pH}$, contact time, adsorbent dose, adsorbate dose, particle size and temperature. Further investigations of this present work include fitting the adsorption process with suitable isotherms such as those of Langmuir, Freundlich, Temkin and DubininRadushkevich, and to establish the kinetics of the adsorption process, as well as to optimize the adsorption process and statistically correlate and justify the importance of the process parameters.

\section{MATERIALS AND METHODS}

\subsection{Materials}

Banana peel (Musa Acuminata) was collected from the local market in Bariga, Lagos, while coconut shell (Cocos nucifera L.) was obtained from Badagry, Lagos, Nigeria.

\subsubsection{Adsorbent preparation}

The banana peel was prepared by adopting the method of Abbasi et al., (2013) and Taimur et al. (2012). It was washed thoroughly with distilled water to remove dust and soil, dried in sunlight for 5 days and kept in an oven at $70^{\circ} \mathrm{C}$. The dried peel was then cut into small pieces, after which it was ground. The coconut shell was prepared based on the method used by Ayub and Khorasgani (2014) and Tharannum et al. (2015). After collection it was sun dried for 2 days, crushed with a hammer mill, sieved and pre-treated with $0.1 \mathrm{M} \mathrm{NaOH}$ for 3 hours, then washed with distilled water to remove dust, soil and $\mathrm{NaOH}$ traces. The adsorbent was sieved and dried again at $50{ }^{\circ} \mathrm{C}$ in an oven. It was then stored in desiccators for use. 


\subsubsection{The adsorbate}

Nickel(II) nitrate hexahydrate was used as the adsorbate and was obtained from Finlab, Ikorodu Road, Lagos. It was prepared according to the method adopted by Gonen and Serin (2012). $\mathrm{Ni}$ (II) ions were prepared by diluting $1000 \mathrm{mg} / \mathrm{L}$ of $\mathrm{Ni}\left(\mathrm{NO}_{3}\right)_{2} .6 \mathrm{H}_{2} \mathrm{O}$ stock solution with distilled water to a desired concentration range of between 10 and $200 \mathrm{mg} / \mathrm{L}$.

\subsubsection{Apparatus and reagents used}

The following apparatus and reagents were used: analytical grade nitric acid $\left(\mathrm{HNO}_{3}\right)$; analytical grade sodium hydroxide $(\mathrm{NaOH})$; analytical grade nickel(II) nitrate hexahydrate salt [Ni $\left(\mathrm{NO}_{3}\right)_{2} .6 \mathrm{H}_{2} \mathrm{O}$ ]; a mesh sieve B.S.S (200); Buck atomic absorption spectrophotometer (AAS); hammer mill; electric water bath; electric oven; electric water bath; graduated beakers and cylinders; Whatman filter paper; electronic weighing balance; electronic $\mathrm{pH}$ meter; furnace; funnels; stopwatch and distilled water.

\subsection{Experimental Procedure}

The initial $\mathrm{pH}$ of the solutions was adjusted by $0.1 \mathrm{M} \mathrm{NaOH}$ or $0.1 \mathrm{M} \mathrm{HNO}$. All the experiments were carried out at room temperature, and the initial and final metal ion concentrations were determined using the AAS. All runs were conducted three times, with averages taken. The \% removal of the $\mathrm{Ni}$ (II) ion and the amount of $\left(\mathrm{q}_{\mathrm{e}}\right)$ adsorbed on the coconut shell and banana peel were calculated using Equations 1 and 2, respectively:

$$
\begin{gathered}
\operatorname{Removal}(\%)=\frac{100\left(c_{0}-c_{B}\right)}{c_{0}} \\
\mathrm{q}_{\mathrm{e}}=\frac{c_{0} \mathrm{~V}_{0}-c_{\mathrm{B}} \mathrm{V}_{\mathrm{B}}}{m}
\end{gathered}
$$

where $C_{e}$ is the equilibrium concentration of the mixture in $\mathrm{mg} / \mathrm{L} ; \mathrm{C}_{0}$ is the initial concentration of the mixture in $\mathrm{mg} / \mathrm{L} ; \mathrm{m}$ is the mass of the adsorbent in grams; $q_{e}$ is the amount of solute removed or adsorbed at equilibrium in $\mathrm{mg} / \mathrm{g} ; V_{o}$ is the initial volume of simulated oil spill in $\mathrm{L}$; and $\mathrm{V}_{\mathrm{e}}$ is the final volume of simulated oil spill at equilibrium in $\mathrm{L}$.

\subsubsection{Effect of temperature on adsorption}

Exactly $50 \mathrm{ml}$ of $100 \mathrm{mg} / \mathrm{L}$ of the $\mathrm{Ni}$ solution was prepared from the stock solution using distilled water. About $50 \mathrm{ml}$ of the prepared adsorbate was placed into separate $250 \mathrm{ml}$ beakers and $2.5 \mathrm{~g}$ of each adsorbent (banana peel and coconut shell) was added to the beakers. The beakers were placed in a water bath shaker for 20 minutes at $120 \mathrm{rpm}$. This step was then repeated with temperature ranges from 20 to $60^{\circ} \mathrm{C}$. The adsorbents were filtered out with filter paper and funnels, while the filtrate concentrations were determined by the AAS. Average ambient temperature was at $27^{\circ} \mathrm{C}$.

\subsubsection{Effect of $\mathrm{pH}$}

Exactly $50 \mathrm{ml}$ of $100 \mathrm{mg} / \mathrm{L} \mathrm{Ni}$ solution and $2.5 \mathrm{~g}$ of the adsorbents were poured into separate glass beakers, and the $\mathrm{pH}$ of each solution was adjusted using $0.1 \mathrm{M} \mathrm{NaOH}$. The beakers were placed in an electric water bath shaker for 20 minutes at $120 \mathrm{rpm}$. This was done for $\mathrm{pH}$ values of 1.0-8.0. The resulting solutions were filtered and the concentrations determined using the AAS.

\subsubsection{Effect of adsorbent dose on adsorption}

Up to $50 \mathrm{ml}$ of $100 \mathrm{mg} / \mathrm{L}$ prepared adsorbate was poured into separate beakers and various weighed amounts of the adsorbents $(0.2-1.4 \mathrm{~g})$ were added to each of the beakers. The beakers were placed in an electric water bath shaker for 20 minutes at $120 \mathrm{rpm}$. The resulting filtered concentrations were measured with the AAS. 


\subsubsection{Effect of adsorbate dose on adsorption}

A $50 \mathrm{ml}$ of $100 \mathrm{mg} / \mathrm{L}$ adsorbate was prepared using distilled water in two $250 \mathrm{ml}$ beakers and $2.5 \mathrm{~g}$ of both adsorbents were placed into the adsorbate solutions. The beakers were placed in an electric water bath shaker for 20 minutes at $120 \mathrm{rpm}$. This step was carried out at adsorbate concentrations of $20-100 \mathrm{mg} / \mathrm{L}$. The final concentrations of the filtrates were determined with the AAS.

\subsubsection{Effect of contact time on adsorption}

Exactly $50 \mathrm{ml}$ of $100 \mathrm{mg} / \mathrm{L}$ adsorbate was poured into separate glass beakers. Up to $2.5 \mathrm{~g}$ of the adsorbents were added into the beakers containing the adsorbate, and the beakers were placed in the electric water bath shaker at $120 \mathrm{rpm}$ for 5 minutes. This step was made at varying contact times, from 5 to 60 minutes. The resulting mixtures were filtered and placed in the AAS to measure their concentrations.

\subsubsection{Effect of particle size on adsorption}

Exactly $50 \mathrm{ml}$ of $100 \mathrm{mg} / \mathrm{L}$ of the adsorbate solution was poured into separate glass beakers. Exactly $2.5 \mathrm{~g}$ and 53 microns of each adsorbent were then mixed with the adsorbate, and the beakers were placed in an electric water bath shaker for 20 minutes at $120 \mathrm{rpm}$. This step was made for varying particle sizes, up to 250 microns. The final filtrate concentrations were determined with the AAS.

\section{RESULTS AND DISCUSSION}

\subsection{Effect of Adsorbent Dose on Adsorption}

From Figure 1, it can be seen that the percentage removal of each adsorbent rose with increasing adsorbent dosage, but tended to remain constant at about $1.3 \mathrm{~g}$. This may be due to overlapping of the adsorption sites as a result of overcrowding of the adsorbent particles. A similar explanation was given by Suresha and Deepa (2014) for the biosorption of Ni(II) ions from aqueous solution using Araucaria cookie leaves.

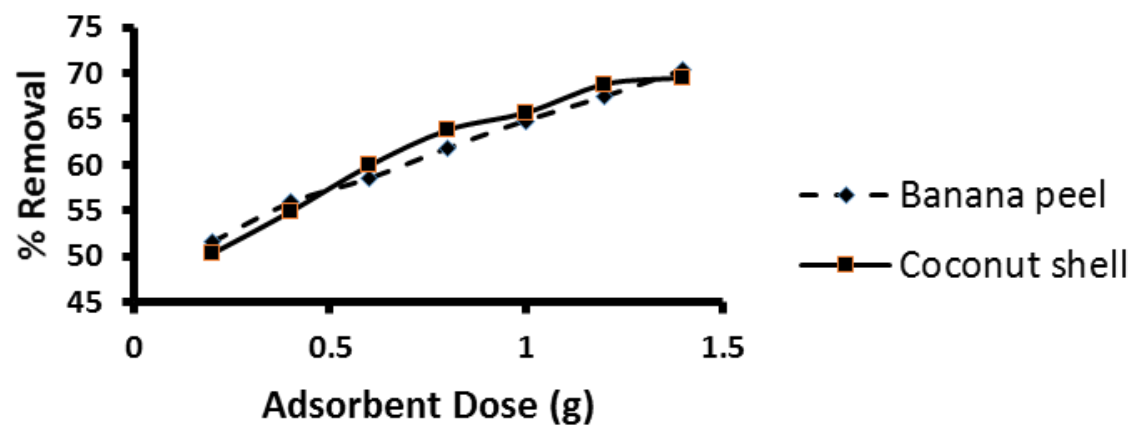

Figure1 Effect of varying adsorbent doses on adsorption

\subsection{Effect of $\mathbf{p H}$ on Adsorption}

Figure 2 shows that increments in $\mathrm{pH}$ resulted in a high percentage removal, and remained constant for $\mathrm{pH}$ values of about 6 to 8 . This is due to the fact that $\mathrm{pH}$ has a significant effect on adsorption because it affects the solubility of metal ions, the concentration of counter ions on the functional group of the adsorbent, and the degree of ionization of the adsorbate during the reaction. Sorption does not seem to occur in highly acidic and alkaline conditions because hydrogen ions and hydroxyl ions compete for active sites on the adsorbent surface, as reported by Shah et al. (2016). 


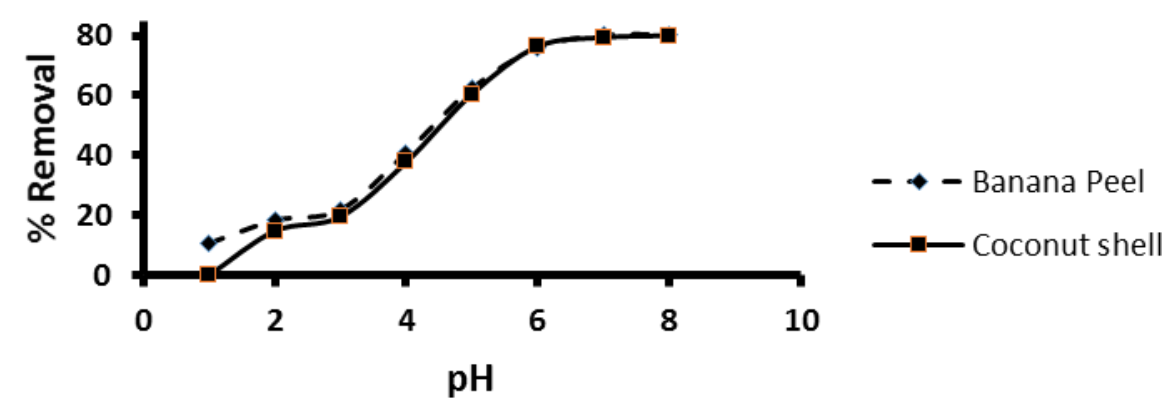

Figure 2 Effect of varying $\mathrm{pH}$ on adsorption

\subsection{Effect of Contact Time on Adsorption}

It is evident from Figure 3 that an increase in contact time favors only adsorption using banana peel as the adsorbent. Decreasing the contact time between the solution and coconut shell would improve the percentage removal. It seems that banana peel has more capacity than coconut shell for adsorption. Increases in time are expected to enhance sorption until saturation at equilibrium. From the observed phenomenon, the optimized maximum uptake of banana peel compared to coconut shell seems to be higher, as reported separately by Annadurai et al., (2002) and Aziz et al. (2005).

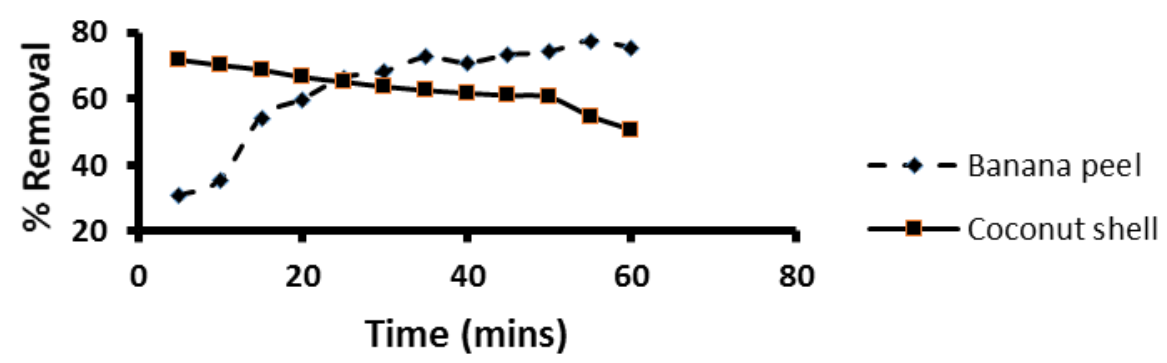

Figure 3 Effect of contact time on adsorption

\subsection{Effect of Temperature on Adsorption}

As shown in Figure 4, with an increase in temperature the percentage removal decreases as a result of the desorption taking place; that is, the nickel ions do not attach themselves properly to the adsorbent as the temperature is increased over time. Naturally, temperature increases the kinetic energy of the ions and molecules in solution, which has an adverse effect on the adsorption. Similar accounts were given by Matouq et al. (2015) for the sorption of nickel onto moringa pods, and by Hannachi et al. (2014) for the adsorption of nitrate ions onto a membrane.

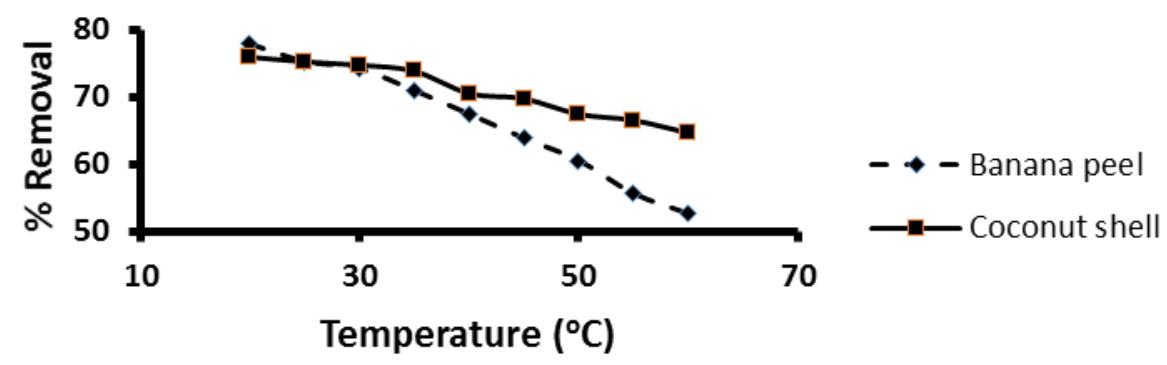

Figure 4 Effect of temperature on adsorption 


\subsection{Effect of Adsorbate Concentration on Adsorption}

Increasing the adsorbate concentration slightly reduced the percentage removal for banana, while it appeared constant for coconut shell, as shown in Figure 5. Increasing adsorbate concentration presented a situation whereby more ions were provided to be adsorbed, without increasing the adsorbent quantity. This led to supersaturation of the active sites available for adsorption. Matouq et al. (2015) and Khelifi et al. (2016) similarly reported that as the initial concentration for metal ions increases, the removal percentage decreases for a fixed adsorbent dose and contact time. This behavior was also explained by the limited active site on the adsorbent surface.

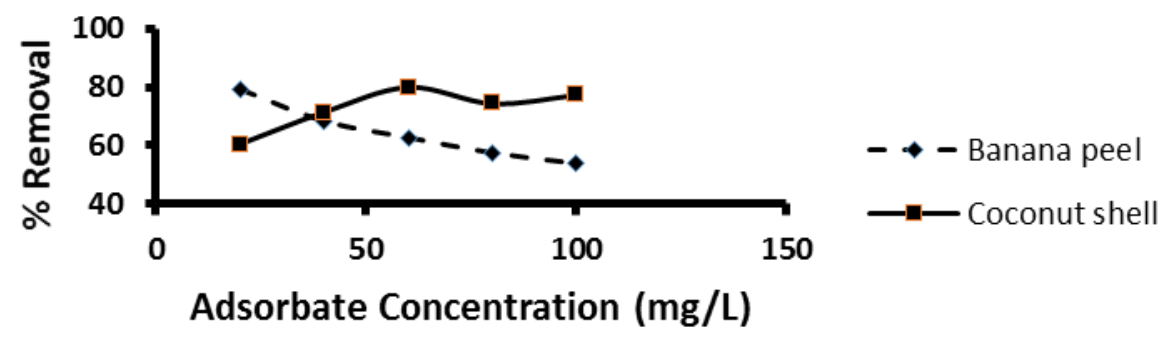

Figure5 Effect of adsorbate concentration

\subsection{Effect of Particle Size on Adsorption}

As shown in Figure 6, the percentage removal by adsorption fell with increased particle size. This could be explained from the fact that as the particle size increased, the active available surface area decreased, which hindered adsorption for both adsorbents. The same parametric observation was made by Hossain et al. (2012).

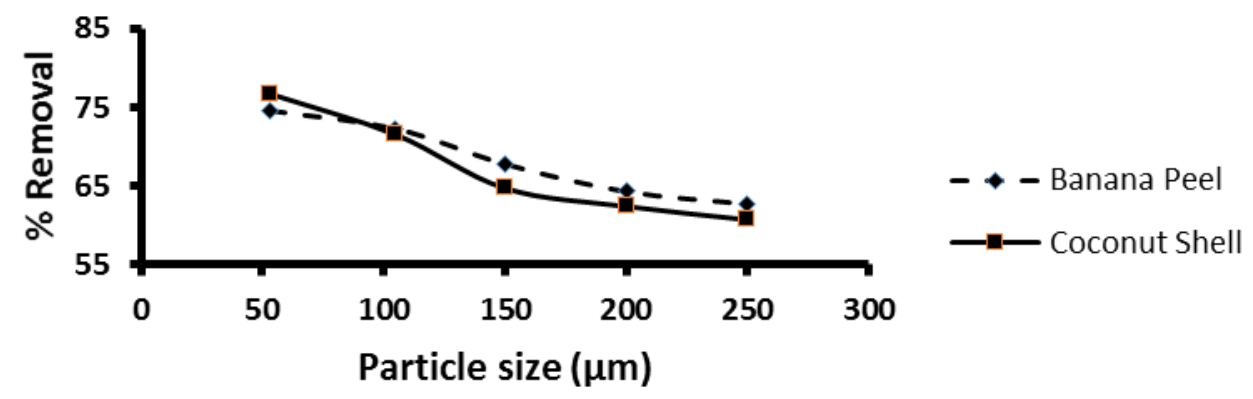

Figure 6 Percentage Removal with Varying Particle Size

\subsection{Theoretical Statistical Experiment Design}

Design Expert 9 was used to design the experiment. It was employed to check for the interdependence of more than one factor by identifying their overall effect. A full factorial experiment design was used. Subsequently, the percentage removal was calculated.

\subsubsection{Full factorial design}

The main factors (adsorbent dose, temperature and contact time) were selected, as well as their factor levels, coded as -1 (low) and +1 (high), as seen in Table 1. A full $\mathbf{2}^{\mathbf{3}}$ factorial design was employed and a matrix generated. The factor levels were coded as -1 (low) and +1 (high), as seen in the Table. The percentage removal results obtained are presented in Table 2. 
Table 1 High and low values for the main factors

\begin{tabular}{lcc}
\hline \multicolumn{1}{c}{ Factors } & Low $(-1)$ & High $(+1)$ \\
\hline Adsorbent dose & $0.5 \mathrm{~g}$ & $4.5 \mathrm{~g}$ \\
Contact time & $30 \mathrm{mins}$ & $120 \mathrm{mins}$ \\
Temperature & $25^{\circ} \mathrm{C}$ & $65^{\circ} \mathrm{C}$ \\
\hline
\end{tabular}

Table 2 Percentage removal obtained

\begin{tabular}{cccccccccc}
\hline \multicolumn{2}{c}{ Run } & 1 & 2 & 3 & 4 & 5 & 6 & 7 & 8 \\
\hline \multirow{2}{*}{ \% Removal } & Banana peel & 40.42 & 47.23 & 55.89 & 61.02 & 68.45 & 74.53 & 78.16 & 80.1 \\
& Coconut shell & 41.80 & 44.40 & 50.70 & 56.90 & 67.20 & 72.50 & 70.30 & 68.4 \\
\hline
\end{tabular}

As previously observed, banana peel seems to be a better adsorbent for nickel under similar conditions, which is confirmed by the findings of Annadurai et al. (2002) and Aziz et al., (2005).

\subsection{Analysis of Variance and Parametric Statistical Significance}

The ANOVA and Bonferroni-Holm Posthoc significance test results for Nickel (II) ion adsorption by banana peel and coconut shell with varying parameters are given in Table 3 . The statistical computation presented was carried out with the aid of Daniel's XL Toolbox Version 6.70 @ $2008-2013$ software.

Table 3 Bonferroni-holm posthoc significance test and analysis of variance (ANOVA) for Nickel (II) ion adsorption with banana peel and coconut shell, using varying parameters

\begin{tabular}{|c|c|c|c|c|c|c|c|c|c|c|}
\hline \multirow{2}{*}{$\begin{array}{c}\text { Group } \\
1\end{array}$} & \multirow{2}{*}{$\begin{array}{c}\text { Group } \\
2\end{array}$} & \multicolumn{3}{|c|}{$\begin{array}{l}\text { Bonferroni-Holm Posthoc } \\
\text { Significance Test }\end{array}$} & \multicolumn{6}{|c|}{ Analysis of Variance (ANOVA) Test } \\
\hline & & $\mathrm{P}_{\mathrm{C}}$ & $\mathrm{P}$ & Significant & $\mathrm{S}_{\mathrm{SB}}$ & $\mathrm{S}_{\mathrm{Sw}}$ & $\mathrm{D}_{\mathrm{FB}}$ & $\mathrm{D}_{\mathrm{FW}}$ & $\mathrm{F}$ & $\mathrm{P}$ \\
\hline $\mathrm{W}_{\mathrm{B}}$ & $P_{R}$ & 0.0167 & $1.449 \mathrm{E}-11$ & Yes & 17283.91 & & 2 & & & \\
\hline $\mathrm{W}_{\mathrm{C}}$ & $P_{R}$ & 0.0250 & $3.712 \mathrm{E}-11$ & Yes & & $5 / 3.6 /$ & & 18 & $2 / 1.15$ & 3.64 \\
\hline $\mathrm{pH}_{\mathrm{B}}$ & $P_{R}$ & 0.0167 & 0.000846 & Yes & 9841.02 & & 2 & & & \\
\hline $\mathrm{pH}_{\mathrm{C}}$ & $P_{R}$ & 0.0250 & 0.002678 & Yes & & 13391.19 & & 21 & 1.12 & 0.0031 \\
\hline$t_{B}$ & $P_{R}$ & 0.0167 & $1.35 \mathrm{E}-05$ & Yes & 7503.19 & & 2 & & & 3.91E-06 \\
\hline $\mathrm{t}_{\mathrm{C}}$ & $P_{R}$ & 0.0250 & 0.000198 & Yes & & 6658.63 & & 33 & 18.59 & \\
\hline $\mathrm{T}_{\mathrm{B}}$ & $P_{R}$ & 0.0167 & 7.59E-06 & Yes & 5025.17 & 227582 & 2 & 24 & 2650 & 8.42E-07 \\
\hline $\mathrm{T}_{\mathrm{C}}$ & $P_{R}$ & 0.0250 & 0.000176 & Yes & & & & & & \\
\hline $\mathrm{C}_{\mathrm{AB}}$ & $P_{R}$ & 0.0250 & 0.409121 & No & 414.70 & 462360 & 2 & 12 & 054 & 060 \\
\hline $\mathrm{C}_{\mathrm{AC}}$ & $P_{R}$ & 0.0500 & 0.780217 & No & & 4025.00 & & 12 & 0.54 & 0.00 \\
\hline $\mathrm{S}_{\mathrm{B}}$ & $\mathrm{P}_{\mathrm{R}}$ & 0.0167 & 0.041120 & No & 23428.15 & 2420477 & 2 & 12 & 581 & 00172 \\
\hline$S_{C}$ & $P_{R}$ & 0.0250 & 0.043023 & No & & & & & & \\
\hline
\end{tabular}

where $C_{A}$ is the adsorbate concentration $(\mathrm{mg} / \mathrm{L}), \mathrm{C}_{\mathrm{AB}}$ is the adsorbate concentration with banana peel $(\mathrm{mg} / \mathrm{L}), \mathrm{C}_{\mathrm{AC}}$ is the adsorbate concentration with coconut shell $(\mathrm{mg} / \mathrm{L}), \mathrm{D}_{\mathrm{FB}}$ is the degrees of freedom between groups, $\mathrm{D}_{\mathrm{FW}}$ is the degrees of freedom within groups, $\mathrm{F}$ is Fisher's ratio, $\mathrm{P}$ is the probability factor, $\mathrm{P}_{\mathrm{C}}$ is the critical probability factor, $\mathrm{pH}_{\mathrm{B}}$ is the measured $\mathrm{pH}$ with respect to banana peel, $\mathrm{pH}_{\mathrm{C}}$ is the measured $\mathrm{pH}$ with respect to coconut shell, $\mathrm{P}_{\mathrm{R}}$ is the percentage removal of ions (\% removal), $S_{B}$ is the banana peel particle size $(\mu \mathrm{m}), S_{C}$ is the coconut shell particle size $(\mu \mathrm{m}), \mathrm{S}_{\mathrm{SB}}$ is the sum of squares between the groups, $\mathrm{S}_{\mathrm{SW}}$ is the sum of squares within the groups, $t$ is the mixing time $(\mathrm{min}), \mathrm{t}_{\mathrm{B}}$ is the time with respect to banana peel $(\mathrm{min}), \mathrm{t}_{\mathrm{C}}$ is the time with respect to coconut shell $(\mathrm{min}), \mathrm{T}$ is the temperature $(\mathrm{K}), \mathrm{T}_{\mathrm{B}}$ is the temperature with respect to banana peel $\left({ }^{\circ} \mathrm{C}\right), \mathrm{T}_{\mathrm{C}}$ is the temperature with respect to coconut shell $\left({ }^{\circ} \mathrm{C}\right), \mathrm{W}$ is 
the weight of the adsorbent $(\mathrm{g}), \mathrm{W}_{\mathrm{B}}$ is the adsorbent dose for banana peel $(\mathrm{g})$; and $\mathrm{W}_{\mathrm{C}}$ is the adsorbent dose for coconut shell $(\mathrm{g})$.

The parameters investigated show the actual values of the sum of squares within and between the groups. There exists a statistically wide variation between the individually investigated parameters and the percentage removal of Nickel (II) ion groups at the 95\% confidence interval, as the $\mathrm{F}$ and $\mathrm{P}$ values are mostly within the expected ranges. Fisher's $\mathrm{F}$ is a ratio of the variance between groups to the variance within groups, and $\mathrm{P}$ is a probability factor that must be less than 0.05 in the ANOVA analysis.

The degree of freedom between the groups was 2, while the degree of freedom within them varied from 12 to 33. The $\mathrm{F}$ and $\mathrm{P}$ values implied a strong dependence of $\mathrm{P}_{\mathrm{R}}$ on the various parameters investigated. The Bonferroni-Holm Posthoc parametric significance test for various parameters investigated showed a strong dependence or significance on each other, except for the relationships between $\mathrm{P}_{\mathrm{R}}$ and $\mathrm{C}_{\mathrm{AB}}, \mathrm{C}_{\mathrm{AC}}, \mathrm{S}_{\mathrm{B}}$ and $\mathrm{S}_{\mathrm{C}}$ with $\mathrm{P}$ values greater than the $\mathrm{P}_{\mathrm{C}}$ values in the $95 \%$ confidence interval. In comparison with previous literature, the parametric variables that furnished the maximum percentage removal of ions with similar adsorbent or adsorbate systems conformed with the work of Chaudhari (2009) and Abbasi et al., (2013). In agreement with the statistical Bonferroni-Holm Posthoc parametric significance test in Table 3, none were obtained under adsorbate nor particle size variation. In conformity with the results obtained from this work, similarities between them can be drawn, as the maximum percentage removal obtained from the use of banana peel was $80.3 \%$, and from coconut shell it was $80 \%$, under the same conditions of $\mathrm{pH}$ variation.

\subsubsection{Adsorption isotherms}

The Langmuir isotherm was expressed using Equation 3 below:

$$
\frac{C_{e}}{q_{e}}=\frac{1}{Q_{0} b}+\frac{C_{e}}{Q_{0}}
$$

$Q_{0}$ is the Langmuir constant for maximum adsorption capacity, and $\mathrm{b}$ is the Langmuir constant. The essential characteristics of the Langmuir isotherm can be expressed in terms of a dimensionless constant separation factor or equilibrium parameter, $\mathrm{R}_{\mathrm{L}}$, which is defined in Equation 4 by:

where $\mathrm{C}_{\mathrm{o}}$ is the initial concentration.

$$
R_{L}=\frac{1}{1+b c_{0}}
$$

The Freundlich isotherm is often expressed in Equation 5 as:

$$
\log q_{e}=\log \mathrm{K}_{\mathrm{f}}+\frac{1}{n} \log C_{e}
$$

where $K_{F}$ and $\mathrm{n}$ are the Freundlich constants.

The Langmuir and Freundlich adsorption isotherm constants are given in Table 4, while the Temkin and Dubinin-Radushkevich adsorption isotherm constants are presented in Table 5. $A_{T}$ is the Temkin isotherm equilibrium binding constant $(\mathrm{L} / \mathrm{mg}) ; \mathrm{B}$ is the Temkin constant related to heat of adsorption; $b_{T}$ is the Temkin isotherm constant $(\mathrm{J} / \mathrm{mol}) ; E$ is the DubininRadushkevich isotherm parameter; $K_{a d}$ is the Dubinin-Radushkevich isotherm constant $\left(\mathrm{mol}^{2} / \mathrm{kJ}^{2}\right) ; q_{s}$ is the theoretical isotherm saturation capacity $(\mathrm{mg} / \mathrm{g}) ; \mathrm{R}$ is the Universal Gas Constant $(8.314 \mathrm{~J} / \mathrm{mol} \mathrm{K}) ; R^{2}$ is the Coefficient of Regression; and $\mathrm{T}$ is Temperature $(\mathrm{K})$. 
Table 4 Langmuir and Freundlich adsorption isotherm constants

\begin{tabular}{lccccccc}
\hline \multirow{2}{*}{ Adsorbent } & \multicolumn{3}{c}{ Langmuir Constants } & \multicolumn{3}{c}{ Freundlich Constants } \\
\cline { 2 - 8 } & $\mathrm{Q}_{\mathrm{o}}(\mathrm{mg} / \mathrm{g})$ & $\mathrm{b}(\mathrm{L} / \mathrm{mg})$ & $\mathrm{R}^{2}$ & $\mathrm{R}_{\mathrm{L}}$ & $\mathrm{K}_{\mathrm{F}}(\mathrm{L} / \mathrm{mg})$ & $\mathrm{n}$ & $\mathrm{R}^{2}$ \\
\hline Banana Peel & 1.47 & 0.018 & 0.9821 & 0.356 & 0.004 & 0.263 & 0.9202 \\
Coconut Shell & 2.57 & 0.016 & 0.9744 & 0.384 & 0.016 & 0.33 & 0.9619 \\
\hline
\end{tabular}

Table 5 Temkin and Dubinin-Radushkevich adsorption isotherm constants

\begin{tabular}{lcccccccc}
\hline \multirow{2}{*}{ Adsorbent } & \multicolumn{4}{c}{ Temkin Constants } & \multicolumn{4}{c}{ Dubinin-RadushkevichConstants } \\
\cline { 2 - 9 } & $\begin{array}{c}\mathrm{B} \\
(\mathrm{J} / \mathrm{mol})\end{array}$ & $\begin{array}{c}\mathrm{A}_{\mathrm{T}} \\
(\mathrm{L} / \mathrm{g})\end{array}$ & $\mathrm{B}$ & $\mathrm{R}^{2}$ & $\mathrm{~K}_{\mathrm{ads}}\left(\mathrm{mol}^{2} / \mathrm{kJ}^{2}\right)$ & $\begin{array}{c}\mathrm{q}_{\mathrm{s}} \\
(\mathrm{mg} / \mathrm{g})\end{array}$ & $\mathrm{R}^{2}$ & $\begin{array}{c}\mathrm{E}_{\mathrm{D}} \\
(\mathrm{kJ} / \mathrm{mol})\end{array}$ \\
\hline $\begin{array}{l}\text { Banana } \\
\begin{array}{l}\text { Peel } \\
\text { Coconut }\end{array}\end{array}$ & 19.308 & 0.034 & 117.55 & 0.7312 & 0.0005 & 23.96 & 0.8338 & 44.72 \\
Shell & 17.513 & 0.036 & 129.6 & 0.8355 & 0.0004 & 22.21 & 0.9087 & 50 \\
\hline
\end{tabular}

From Table 4, it can be seen that the Langmuir isotherm for banana peel gave the best fit for the adsorption operation, similar to the observations of Amer et al., (2015). Favorable adsorption was achieved as a result of the fact that $0<R_{\mathrm{L}}<1$. In Table 5, the Temkin and DubininRadushkevich adsorption isotherms also gave good $\mathrm{R}^{2}$ values, but are not as high as those of the Langmuir isotherm obtained for banana peel, as shown in Table 4.

The Temkin and Dubinin-Radushkevich constants were both accounted for in order to estimate certain energy adsorption related parameters. The Dubinin-Radushkevich isotherm is more general than that of Langmuir because its deviations are not based on ideal assumptions, such as the equipotential of sorption sites, absence of steric hindrances between sorbed and incoming particles, and surface homogeneity at the microscopic level. The isotherm with the highest $\mathrm{R}^{2}$ value proves to be a better choice in explaining sorption energies. From Table 5, the mean free energy obtained, $E_{D}$, was greater than $8 \mathrm{~kJ} / \mathrm{mol}$, which is an indication from DubininRadushkevicht hat the operation suggested chemisorptions. Rao and Khan (2017) suggest close observations.

\subsubsection{Kinetic studies}

The pseudo first order kinetic model is given in Equation 6 as:

$$
\log \left(\mathrm{q}_{\mathrm{e}}-\mathrm{q}_{\mathrm{t}}\right)=\log \mathrm{q}_{\mathrm{e}}-\left(\mathrm{K}_{1} / 2.303\right) \mathrm{t}
$$

The pseudo second order kinetic model is given in Equation 7 as:

$$
\frac{t}{\mathrm{q}_{\mathrm{t}}}=\frac{1}{h}+\frac{1}{\mathrm{q}_{\mathrm{e}} \mathrm{t}}
$$

where, $q_{t}$ is the amount of solute adsorbed at time $\mathrm{t}$ in $\mathrm{mg} / \mathrm{g}$, $\mathrm{h}$ and $\mathrm{K}_{1}$ are constants.

The constants from the plots of the pseudo first and second order kinetics are given in Table 6 . It can be seen that the pseudo second order kinetics gave a better fit for the two adsorbents, which is similar to the reports of Amer et al. (2015) and Ajayi-Banji et al. (2016) for the biosorption of contaminated wastewater with coconut shell husk. 
Table 6 Pseudo first and second order kinetic constants

\begin{tabular}{lcccccc}
\hline \multirow{2}{*}{ Adsorbent } & \multicolumn{3}{c}{ Pseudo First Order Constants } & \multicolumn{3}{c}{ Pseudo Second Order Constants } \\
\cline { 2 - 7 } & $\mathrm{K}\left(\mathrm{min}^{-1}\right)$ & $\mathrm{R}^{2}$ & $\mathrm{q}_{\mathrm{e}}(\mathrm{mg} / \mathrm{g})$ & $\mathrm{h}\left(\mathrm{gmg}^{-1} \mathrm{~min}^{-1}\right)$ & $\mathrm{q}_{\mathrm{e}}(\mathrm{mg} / \mathrm{g})$ & $\mathrm{R}^{2}$ \\
\hline Banana Peel & 0.044 & 0.1106 & 0.663 & 0.047 & 0.0140 & 0.8537 \\
Coconut Shell & 0.025 & 0.0387 & 0.196 & 0.047 & 0.0099 & 0.7628 \\
\hline
\end{tabular}

Figures $7 \mathrm{a}$ and $7 \mathrm{~b}$ give the Scanning Electron Microscope (SEM) images of banana peel and coconut shell before and after adsorption at 671 microns ( $\times 400$ magnification), respectively. In both cases, the swelling of the adsorbents and site occupation of sorbent active sites are noticeable.

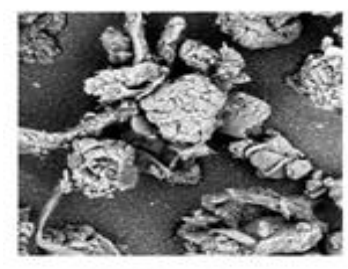

(a) Before Adsorption

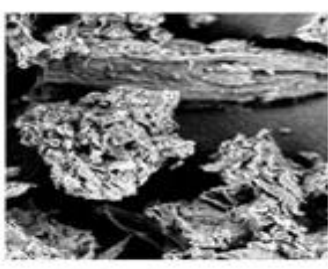

(b) After Adsorption

(a) Banana Peel
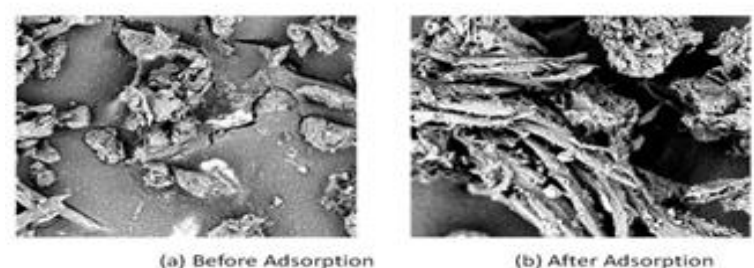

(b) After Adsorption

(b) Coconut Shell

Figure 7 Scanning electron microscope images of banana peel and coconut shell before and after adsorption at 671 microns ( $\times 400$ Magnification)

\section{CONCLUSION}

It has been shown that banana peel and coconut shell are both good adsorbents for the retrieval of $\mathrm{Ni}$ (II) ions with consideration of the six parameters, but that banana peel has a higher percentage removal for most of the factors. The ideal $\mathrm{pH}$ for obtaining the maximum amount of $\mathrm{Ni}$ (II) ion uptake by the adsorbents was 8 , so this can be considered to be the optimum dosage in specific conditions. A very good comparative percentage, similar to existing works, was also obtained in this study. From the experimental approach design, the highest percentage removal for banana peel suggested an adsorbent dose of $4.5 \mathrm{~g}$, contact time of 120 mins and temperature of $25^{\circ} \mathrm{C}$, while the conditions for the maximum $\mathrm{Ni}$ (II) ion uptake using coconut shell are $4.5 \mathrm{~g}$ adsorbent dose, 30 min contact time and temperature of $25^{\circ} \mathrm{C}$. The percentage removal of $\mathrm{Ni}$ (II) ions was found to decrease with increasing temperature for both adsorbents, which indicated the exothermic nature of the process. The adsorption operation was in close agreement with the Langmuir isotherm for both adsorbents, indicating a monolayer adsorption process. The constants obtained from the Langmiur and Freundlich adsorption isotherms had similar values to those of Chaudhari (2009). The statistical test with ANOVA and BonferroniHolm Posthoc parametric significance test gave good insight into the significance and interdependencies of variables, or the parameters needed for improved and more focused future operations. Lastly, banana peel and coconut shell are effective adsorbents for the removal of Nickel(II) ions from their aqueous solution, with the highest removal for coconut shell obtained at $75.9 \%$, and at $77.8 \%$ for banana peel, at $20{ }^{\circ} \mathrm{C}$. These adsorbents are cost effective and could be considered for the treatment of heavy metals present in industrial wastewater.

\section{ACKNOWLEDGEMENT}

The supporting services and useful advice during the experimental stage of this work provided by the Chemical and Petroleum Engineering Department, as well as the Central Research Laboratory, of the University of Lagos, Akoka, Yaba, Lagos are greatly appreciated. 


\section{REFERENCES}

Abbas, M.N., Abbas, F.S., Ibrahim, S.A., 2014. Cyanide Removal from Wastewater by using Banana Peel. Journal of Asian Scientific Research, Volume 4(5), pp. 239-247

Abbasi, Z., Alikarami, M., Nezhad, E.R., Moradi, F., Moradi, V., 2013. Adsorptive Removal of $\mathrm{Co}^{2+}$ and $\mathrm{Ni}^{2+}$ by Peels of Banana from Aqueous Solution. Universal Journal of Chemistry, Volume 1(3), pp. 90-95

Ajayi-Banji, A., Ajimo, A., Igbode, I.O., 2016. Biosorbability of Coconut Husk Char in Polyatomic Ions Sequestration from Contaminated Surface Water. International Journal of Technology, Volume 7(5), pp. 748-754

Amer, M.W., Ahmad, R.A., Awwad, A.M., 2015. Biosorption of Cu(II), Ni(II), Zn(II) and $\mathrm{Pb}$ (II) Ions from Aqueous Solution by Sophora japonica Pods Powder. International Journal of Industrial Chemistry, Volume 6(1), pp. 67-75

Annadurai, G., Juang, R., Lee, D., 2002. Adsorption of Heavy Metals using Banana and Orange Peels. Water Science and Technology, Volume 47(1), pp. 185-190

Ayub, S., Khorasgani F., 2014. Adsorption Process for Wastewater Treatment by using Coconut Shell Research. Journal of Chemical Sciences, Volume 4(12), pp. 1-8

Aziz, H.A., Adlan, M.N., Hui, C.S., Zahari, M.S.M., Hameed, B. H., 2005. Removal of Ni, Cd, $\mathrm{Pb}, \mathrm{Zn}$ and Colour from Aqueous Solutions using Potential Low Cost Adsorbents. Indian Journal of Engineering and Material Sciences, Volume 12(3), pp. 248-258

Chaudari, U.E., 2009. Coconut Shell: a Carrier for the Removal of Bismuth from Aqueous Solution. International Journal of Chemistry Science, Volume 7(1), pp. 71-79

Divakaran, R., Paul, A., Anoop, K.K., Kuriakose, V.J., Rajesh, R., 2012. Adsorption of Nickel(II) and Chromium(VI) Ions by Chitin and Chitosan from Aqueous Solutions Containing Both Ions. International Journal of Science and Technology Research, Volume 1(1), pp. 43-50

Garba, Z.N., Ugbaga, N.I., Abdullahi, A.K., 2016. Evaluation of Optimum Adsorption Conditions for Ni(II) and Cd(II) Removal from Aqueous Solution by Modified Plantain Peels (MPP). Beni-Suef University Journal of Basic and Applied Sciences, Volume 5(2), pp. $170-179$

Gonen, F., Serin, D., 2012. Adsorption Study on Orange Peel: Removal of Nickel (II) Ions from Aqueous Solution. African Journal of Biotechnology, Volume 11(5), pp. 1250-1258

Gong, W., Yu, Y., Liang, G., Liu, X., Cui, B., Bai, J., Han, P., 2018. Factor Effects and Mechanisms of the Adsorption of $\mathrm{Hg}(\mathrm{II}), \mathrm{Cd}(\mathrm{II})$ and $\mathrm{Ni}(\mathrm{II})$ on Charged Liposomes. Colloids and Surfaces A: Physicochemical and Engineering Aspects, Volume 538, pp. 460-466

Hannachi, C., Guesmi, F., Missaoui, K., Hamrouni, B., 2014. Application of Adsorption Models for Fluoride, Nitrate and Sulfate Ion Removal by AMX membrane. International Journal of Technology, Volume 5(1), pp. 60-69

Hossain, M.A., Ngo, H.H., Guo, W.S., Nguyen, T.V., 2012. Biosorption of Cu(II) from Water by Banana Peel based Biosorbent: Experiments and Models of Adsorption and Desorption. Journal of Water sustainability, Volume 2(1), pp. 87-104

Idris, U.D., Aigbodion, V.S., Abubakar, I.J., Nwoye, C.I., 2015. Eco-friendly Asbestos free Brake-pad: Using Banana Peels. Journal of King Saud University-Engineering Sciences, Volume 27(2), pp. 185-192

Khelifi, O., Nacef, M., Affoune, A.M., 2016. Biosorption of Nickel(II) Ions from Aqueous Solutions by using Chicken Eggshells as Low-cost Biosorbent. Algerian Journal of Environmental Science and Technology, Volume 2(1), pp. 1-12

Matouq, M., Jildeh, N., Qtaishat, M., Hindiyeh, M., Al Syouf, M.Q., 2015. The Adsorption Kinetics and Modeling for Heavy Metals Removal from Wastewater by Moringa Pods. Journal of Environmental Chemical Engineering, Volume 3(2), pp. 775-784 
Okafor, P., Okon, P., Daniel, E., Ebenso, E., 2012. Adsorption Capacity of Coconut (Cocos nucifera L.) Shell for Lead, Copper, Cadmium and Arsenic from Aqueous Solutions. International Journal of Electrochemical Science, Volume 7(12), pp. 12354-12369

Olayinka, O.K., Oyedeji, A.O., Oyeyiola, O.A., 2009. Removal of Chromium and Nickel Ions from Aqueous Solution by Adsorption on Modified Coconut Husk. African Journal of Environmental Science and Technology, Volume 3(10), pp. 286-293

Pino, G.H., de Mesquita, L.M.S., Torem, M.L., Pinto, G.A.S., 2006. Biosorption of Cadmium by Green Coconut Shell Powder. Minerals Engineering, Volume 19(5), pp. 380-387

Rao, R.A.K., Khan, U., 2017. Adsorption of Ni(II) on Alkali Treated Pineapple Residue (Ananas comosus L.): Batch and Column Studies. Groundwater for Sustainable Development, Volume 5, pp. 244-252

Shah, J., Kumar, S., Sharma, S., Sharma, R., Sharma, R., 2016. Removal of Nickel from Aqueous Solution by using Low Cost Adsorbents: A Review. International Journal of Scientific Engineering and Applied Science (IJSEAS), Volume 2(7), pp. 48-73

Sheng, G., Huang, C., Chen, G., Sheng, J., Ren, X., Hu, B., Ma, J., Wang, X., Huang, Y., Alsaedi, A., Hayat, T., 2018. Adsorption and Co-Adsorption of Graphene Oxide and Ni(II) on Iron Oxides: a Spectroscopic and Microscopic Investigation. Environmental Pollution, Volume 233, pp. 125-131

Soco, E., Kalembkiewicz, J., 2013. Adsorption of Nickel(II) and Copper(II) Ions from Aqueous Solution by Coal Fly Ash. Journal of Environmental Chemical Engineering, Volume 1(3), pp. 581-588

Song, C., Cheng, S., Wu, S., Tao, C., Shao, M., Gao, G., 2013. Adsorption Studies of Coconut Shell Carbons Prepared by $\mathrm{KOH}$ Activation for Removal of Lead (II) from Aqueous Solutions. Sustainability, Volume 6(1), pp. 86-98

Suresha, S., Deepa, C.N., 2014. Biosorption of Ni(II) Ions from Aqueous Solution using Leaves of Araucaria cookie. Factors influencing the Biosorption of Nickel. International Journal of Applied Sciences (IJAS), Singaporean Journal of Scientific Research (SJSR), Volume 6(1), pp. 9-16

Taimur, K., Muhammad, A., Chadhuri, M., 2012. Banana Peel: A Low Cost Adsorbent for Removal of Reactive Dye from Aqueous Solution. Universiti Teknologi PETRONAS

Tharannum, S., Krishna, V., Nandini, V., Shruthi, P., 2015. Toxic Heavy Metal Chromium Remediation by Processed Low Cost Adsorbent Green Coconut Shell. The Online Journal of Science and Technology, Volume 5(1), pp. 1-6 